Erlenmayer flasks: application to the chicken poly (ADP-ribose) polymerase catalytic domain. Braz. J. Med. Biol. Res. 30:923-928.

14.Mortensen, C. 1995. Clonagem e expressão de hormonios peptídicos humanos em vetores de expressão de baculovirus. Master's degree dissertation. University of São Paulo, Chemistry Institute.

15.Moscardi, F. 1989. Use of viruses for pest control in Brazil: the case of the nuclear polyhedrosis virus of the soybean caterpillar, Anticarsia gemmatalis. Mem. Inst. Oswaldo Cruz 84:51-56.

16.Neutra, R., B.-Z. Levi, and Y. Shoham. 1992. Optimization of protein-production by the baculovirus expression vector system in shake flasks. Appl. Microbiol. Biotechnol. 37:74-78.

17.O'Reilly, D.R., L.K. Miller, and V.A. Luckow. 1992. Baculovirus Expression Vectors: A Laboratory Manual. Freeman, New York.

18.Palomares, L.A. and O.T. Ramirez. 1997. Insect cell culture: recent advances, bioengineering challenge and implications in protein production, p. 25-52. In E. Galindo and O.T. Ramirez (Eds.), Advances in Bioprocess Engineering II. Kluwer Academic Publishers, Dordrecht, The Netherlands.

19.Possee, R.D., C.J. Thomas, and L.A. King. 1999. The use of baculovirus vectors for the production of membrane proteins in insect cells. Biochem. Soc. Trans. 27:928-932.

20.Power, J., P.F. Greenfield, L. Nielsen, and S.

Reid. 1992. Modelling the growth and protein production by insect cells following infection by a recombinant baculovirus in suspension culture. Cytotechnology 9:149-155.

21.Radford, K.M., C. Cavegn, M. Bertrand, A.R. Bernard, S. Reid, and P.F. Greenfield. 1997. The indirect effects of multiplicity of infection on baculovirus expressed proteins in insect cells: secreted and non-secreted products. Cytotechnology 24:73-81.

22.Reuveny, S., Y.J. Kim, C.W. Kemp, and J. Shiloach. 1993. Effect of temperature and oxygen on cell growth and recombinant protein production in insect cell cultures. Appl. Microbiol. Biotechnol. 38:619-623.

23.Scott, R.I., J.H. Blanchard, and C.H.R. Ferguson. 1992. Effects of oxygen on recombinant protein production by suspension cultures of Spodoptera frugiperda (Sf9) insect cells. Enzyme Microb. Technol. 14:798-804.

We thank Dr. Bryan Strauss for proofreading the manuscript. The work carried out in M.C.S.'s laboratory was supported by FAPESP, CNPq, ICGEB, and PRP-USP. The work carried out in C.A.P.'s laboratory was supported by FAPESP and Fundação Butantan. C.A.P. is a recipient of a $C N P q$ research fellowship. C.M. and Y.P. were recipients of FAPESP predoctoral fellowships. Address correspondence to Dr. Carlos A. Pereira, Université Louis Pasteur, Ecole Supérieure de Biotechnologie de Strasbourg, Bd Sebastian Brand, 67400 Illkirch, France. e-mail: pereira@esbs.u-strasbg.fr or Instituto Bu- tantan, Laboratorio de Imunologia Viral, Av. Vital Brasil 1500, 05503-900 São Paulo, Brazil.e-mail:grugel@usp.br

Received 11 July 2001; accepted 4 September 2001.

C.A. Pereira ${ }^{1,4}$, Y. Pouliquen ${ }^{1,4}$, V. Rodas $^{4}$, D. Massotte ${ }^{2}$, C. Mortensen $^{5}$, M.C. Sogayar ${ }^{5}$, and J. Ménissier-de Murcia ${ }^{3}$

${ }^{1}$ Ecole Supérieure de Biotechnologie de Strasbourg

${ }^{2}$ CNRS UPR 9050

${ }^{3}$ CNRS UPR 9003

Strasbourg, France

${ }^{4}$ Instituto Butantan

${ }^{5}$ Universidade de São Paulo

São Paulo, Brazil

For reprints of this or any other article, contact Reprints@BioTechniques.com

\section{Ploidy Determination in Insects}

BioTechniques 31:1268-1269 (December 2001)

Parthenogenesis is often associated with polyploidy. A single population may contain several ploidy levels (7). To estimate the distribution of ploidy levels allozymes or microsatellites can be used, but homozygosity and null alleles can lead to underestimates (6). These estimates can be more or less accurate, but the ploidy level of single individuals can rarely be determined.

In most cases, it is desirable that the estimate of ploidy level is accurate or that the ploidy level of every individual is known. Flow cytometry has previously been used for this purpose $(3,5)$. This method has the disadvantage of requiring expensive equipment. Direct counting of the chromosomes from every individual is accurate but has the disadvantage of being extremely time consuming.

Here, I present an inexpensive and easy method to determine the ploidy level of a single individual if the different chromosome numbers within the species have been previously established. Chromosome numbers can be determined by paraffin sectioning of oocytes or by staining chromosomes in mitosis. The method described below relies on the fact that nuclei with different number of chromosomes are of different size (2). In most species in which sexual forms exist, males can be used as a diploid nuclear size standard if the chromosome number has not been established. A similar approach has been used previously in vertebrates where the erythrocyte size is correlated with ploidy level (1).

Weevils (Otiorhynchus scaber) frozen at $-70^{\circ} \mathrm{C}$ were placed in $1 \times$ Citrate-PBS $(120 \mathrm{mM} \mathrm{NaCl}, 2.7 \mathrm{mM} \mathrm{KCl}$, $10 \mathrm{mM} \mathrm{NaPO}_{4}, \mathrm{pH} 7.2,20 \mathrm{mM}$ sodium citrate). Malpighian tubules were dissected and placed in Citrate-PBS containing $1 / 8$ volume of propidium iodide staining solution $[0.05 \mathrm{mg} / \mathrm{mL}$ propidium iodide, $0.1 \%$ sodium citrate, $0.03 \%$ Nonidet ${ }^{\circledR}$ P-40 (4)]. The Malpighian tubules were stained for $30 \mathrm{~min}$ at room temperature. The nuclei were then photographed with a digital camera at $200 \times$ magnification. To avoid drying and flat- 
Table 1. Average Area and Standard Deviation of the Nuclei from the Three Ploidy Levels

\begin{tabular}{|lccc|}
\hline \multicolumn{2}{c}{$\mathbf{2 n}$} & 3n & $\mathbf{4 n}$ \\
\hline Average Area & 868.3 & 1337.6 & 1686.3 \\
SD & 127.94 & 64.86 & 82.08 \\
$t$-test comparing 2n and 3n & $P=9.58 \times 10^{-8}$ & \\
$t$-test comparing 3n and 4n & $P=6.76 \times 10^{-9}$ & \\
Two-sided $t$-tests assuming unequal variance were performed in Microsoft ${ }^{\circledR}$ \\
Excel ${ }^{\circledR} 2000$.
\end{tabular}

tening of nuclei, the Malpighian tubules are stained and photographed on slides with concave wells covered by cover glass. At least 10 nuclei from every individual are photographed and compared.

The nuclei from the weevil individuals form three distinct size classes with no overlap (Figure 1). Only sphereshaped nuclei were photographed. Most nuclei were of the same size, but some larger nuclei were also present. Only the smaller nuclei were photographed. The larger size is probably due to endopolyploidy. A flow cytometric study of $\mathrm{He}$ liothis virescens (Lepidoptera) showed that, although there may be high endopolyploid chromosome numbers in the Malpighian tubules, most of the nu-

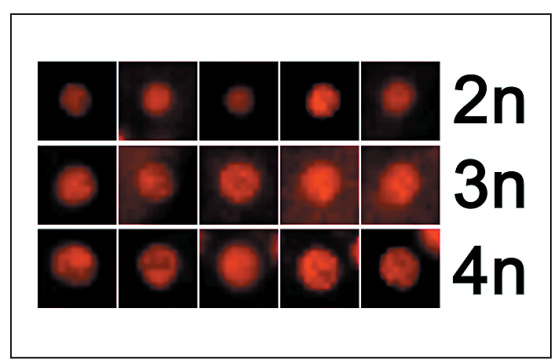

Figure 1. Nuclei from diploid, triploid, and tetraploid Otiorhynchus scaber Malpighian tubules stained with propidium iodide. Photographed at $200 \times$ magnification. clei had the diploid amount of DNA (8).

Using Adobe ${ }^{\circledR}$ Photoshop ${ }^{\circledR} 5.5$ and dot-blot analysis in Gel-Pro ${ }^{\circledR}$ Analyzer 3.0 (Media Cybernetics, Silver Spring, MD, USA), the area of 10 nuclei were measured from three individuals of different ploidy levels. The nuclear area differed significantly among the three forms (Table 1).

I also calculated the volume of the nuclei based on the average area of the three forms. The volume seems to increase linearly with ploidy level (2n: 19247, 3n: 36799, and 4n: 52090; volumes were calculated from the measured areas in Table 1).

To test how applicable the method is to determine ploidy levels in different insects, I dissected Malpighian tubules from Apis mellifera (honeybee), Euura mucronata (bud-galling sawfly), and Coccotrypes dactyliperda (the date pit beetle, Scolytidae) males and females. The males are haploid, and the females diploid in these species. Their nuclei formed two non-overlapping size classes. Figure 2 shows the difference in Apis mellifera.

It is possible to measure the nuclei in the microscope if a camera is not available. Since only the Malpighian tubules are used, the rest of the individual can be used for DNA preparation. It is important that the nuclei of the individuals are intact. Therefore, live material or material that has been frozen alive should be used. Using this method, the ploidy level is determined by comparing the nucleus area from individuals of unknown ploidy level to the nuclei of known ploidy level.

\section{REFERENCES}

1.Austin, N.E. and J.P. Bogart. 1982. Erythrocyte area and ploidy-determination in the salamanders of the Ambystoma jeffersonianum complex. Copeia 1982:485-488.

2.Fankhauser, G. and R.R. Humphrey. 1959. The origin of spontaneous heteroploids in the progeny of diploid, triploid and tetraploid axolotl females. J. Exp. Zool. 142:379-422.

3.Johnson, S.G., R. Hopkins, and K. Goddard. 1999. Constraints on elevated ploidy in hybrid and nonhybrid parthenogenetic snails. J. Hered. 90:659-662.

4.Krishan, A. 1990. Rapid determination of cellular resistance-related drug efflux in tumor cells. Methods Cell Biol. 33:491-500.

5.Normark, B.B. 1996. Polyploidy of parthenogenetic Aramigus tessellatus (Say) (Coleoptera: Curculionidae). Col. Bull. 50:73-79.

6.Ridout, M.S. 2000. Improved estimation of the proportion of triploids in populations with diploid and triploid individuals. J. Hered. 91:57-60.

7.Stenberg, P., J. Terhivuo, J. Lokki, and A. Saura. 2000. Clone diversity in the polyploid weevil Otiorhynchus scaber. Hereditas 132:137-142.

8.Taylor, M., J. Zawadzki, B. Black, and M. Kreitman. 1993. Genome size and endopolyploidy in pyrethroid-resistant and susceptible strains of Heliothis virescens (Lepidoptera: Noctuidae). J. Econ. Entomol. 86:1030-1034.

I wish to thank Benjamin Normark for advice, Anssi Saura for helpful comments, and three anonymous reviewers. I would also like to thank Tommi Nyman for supplying me with sawflies. The study was supported by a grant from the Swedish NFR. Address correspondence to Dr. Per Stenberg, Genetics, Umeå University, SE-901 87 Umeå, Sweden. e-mail:per.stenberg@genetik.umu.se

Received 18 June 2001; accepted 13 September 2001.

\section{Per Stenberg Umeå University \\ Umeå, Sweden}

For reprints of this or any other article, contact Reprints@BioTechniques.com

Figure 2. Nuclei from Apis mellifera male and female. Photographed at $200 \times$ magnification. 